\title{
The Effects of Folic Acid Treatment on Biometric and Blood Parameters of Fingerling Rainbow Trout Fishes (Oncorhynchus mykiss)
}

Abbasian Firouz*, Lameeihassankiadeh Soheil, Khara Hossein, Nezamibaloochi Shabanali, Borani Mohammad and Mohammadalikhan Mehdi

Islamic Azad University, Lahijan, Iran

\begin{abstract}
Folic acid is an essential vitamin for fish farming, and its shortage or extra-administration leads to physiologica dysfunctions and then, to decrease the production efficiency rate. This research studied the effects of two different doses of folic acid (6 and $10 \mathrm{mg} / \mathrm{kg}$ dried food) on different biometric, hematologic and immunological parameters of fingerling rainbow trout fishes (Oncorhynchus mykiss). Totally, we showed that both doses could improve different biometric factors (except for condition index). Furthermore, despite the detrimental effects of these treatments on red blood cells, they could improve immunological functions of the fishes. Since no differences have been observed between the effects of these two folic acid doses, we concluded that treatment of this fish with $6 \mathrm{mg}$ folic acid per kg dried food was as efficient as treatment with $10 \mathrm{mg}$ folic acid.
\end{abstract}

Keywords: Fingerling rainbow trout; Folic acid; Biometry; Hematological factors

\section{Introduction}

Nowadays, malnutrition is a serious situation, afflicting too many people worldwide due to population growth, high demands for food products and natural disasters. The improvement of different agricultural and livestock farming, such as increase in dense fish production efficiency per liter are the possible ways to meet the demands. In turn, since feeding is a critical factor for production of healthy and high-qualified fishes, dense fishery operation is closely depended to the fish nutrition $[1,2]$.

Rainbow trout (Oncorhynchus mykiss) (genus: Oncorhynchus; family: Salmonidae) was originally found in the North America. The fish has been adapted in many fresh water farms worldwide due to its high compatibility to different environmental conditions, high growth rate and its ability to consume different types of food sources. A safe, cost-effective and high-qualified food, containing all required vitamins and minerals, is essential for fish production. The fish is carnivorous and is able to grow under nourishing with commercial foods containing adequate amounts of protein, fat, carbohydrates, vitamins and minerals [3-6]. Since vitamins are necessary for all physiological activities of fishes, including their growth, survive and reproduction, and because natural foods cannot provide the required vitamins, especially in dense farms, extra-administrations is compulsory [7].

Although nutrition is one of main fish farming expenses (40 to $50 \%$ ), the qualification and quantification of many of the food components, including vitamins, has not yet precisely determined for many farmed fish species [8]. This study was designed to determine the optimum intake of folic acid in fingerling rainbow trout and to assay the effect(s) of this vitamin on the fish growth parameters and also on its blood and immune factors.

\section{Material and Methods}

\section{Pond preparation}

Totally, 9 sterile fiberglass tanks (100L) (3 tanks for treatments and 3 tanks for repeats) were filled with well water and were aerated continuously.

\section{Measurement of chemical parameters of water}

Water quality parameters were continuously measured until the end of experiments in order to optimize the living conditions for rainbow trout. Water temperature and dissolved oxygen were assayed 3 times daily while water $\mathrm{pH}$ and salinity were measured once a week; since the water was prepared from a same source through the test, the parameters were constant (7.5 ppm oxygen, $10-12^{\circ} \mathrm{C}$, salinity 0 and $\left.\mathrm{pH} 7.8\right)$.

\section{Rainbow trout}

In this test, first healthy fingerling rainbow trout fishes (obtained from a local aquarium in the north of Iran) were adapted to the water conditions for a week. After cutting their food and anesthesia with $200 \mathrm{ppm}$ gillyflower juice, the biomass parameters of each fingerling was determined and the finger rainbow trout fishes with 7-6 g were entered to the main containers (33 fishes per container). The gillyflower contains Tricaine methan sulfunate (MS222) that cause anesthesia in fish [9].

\section{Food preparation and treatment scheme}

After calculation of the average daily food intake based on the water temperature $\left(10-12^{\circ} \mathrm{C}\right)$ and fish weight [10], their feeding with commercial foods (Cheane Company, Iran) was performed 5 times a day for 2 months ( $2.5 \mathrm{~g}$ food per each fish). Folic acid treatment was performed with two different doses ( 6 and $10 \mathrm{mg} / \mathrm{kg}$ taken dried food). All the treatment and controls were tested three times. The controls were not taken any folic acid and riboflavin.

*Corresponding author: Firouz Abbasian, Islamic Azad University, Lahijan, Iran, E-mail: firouz.abbasian@gmail.com

Received January 06, 2013; Accepted February 25, 2013; Published March 05 2013

Citation: Firouz A, Soheil L, Hossein K, Shabanali N, Mohammad B, et al. (2013) The Effects of Folic Acid Treatment on Biometric and Blood Parameters of Fingerling Rainbow Trout Fishes (Oncorhynchus mykiss). J Aquac Res Development 4: 175 doi:10.4172/2155-9546.1000175

Copyright: (C) 2013 Firouz A, et al. This is an open-access article distributed unde the terms of the Creative Commons Attribution License, which permits unrestricted use, distribution, and reproduction in any medium, provided the original author and source are credited. 
Citation: Firouz A, Soheil L, Hossein K, Shabanali N, Mohammad B, et al. (2013) The Effects of Folic Acid Treatment on Biometric and Blood Parameters of Fingerling Rainbow Trout Fishes (Oncorhynchus mykiss). J Aquac Res Development 4: 175 doi:10.4172/2155-9546.1000175

Page 2 of 4

\section{Biometric and determination of fish growth}

The biometric measurements (weight and length) took place over fortnight and fish body weight gain, body weight percentage, daily growth percentage and survival percentage for each treatment were calculated based on existing formula [11,12].

\section{Blood and blood parameters}

Totally 5 fish from each tanker were accidentally chosen for blood tests. After preparing blood samples from fish artery vein, the heparinated blood samples were analyzed for different blood factors, including red blood cell count (RBC) [13], white blood cell count (WBC) [14], differential white blood cell count [15], hematocrit (PCV) [16], hemoglobin concentration (Hb) [14], MCV [17], MCH [17] and $\mathrm{MCHC}$ [17].

\section{Immunological parameters}

The heparinated blood samples were centrifuged and the prepared serums were stored at $-20^{\circ} \mathrm{C}[18]$. The total protein was measured based on the procedure introduced by Tietz [19]. The concentration of IgM was analyzed by Nephelometery method [20] in which the Antigenanti-IgM polyclonal antibody complex was irradiated with $400-840 \mathrm{~nm}$ waves.

In order to calculate the serum lysozyme activity, the prepared serum samples were immediately stored at $-70^{\circ} \mathrm{C}$ to keep the enzymes away of activation. The lysozyme activity of serums was performed based on lysis of Micrococcus lysodeikticus suspension (Sigma, St. Louis, USA) by the enzyme. The bacterial lysis activity was measured by optimal density (OD) in $450 \mathrm{~nm}$ [18].

Finally, the total hemolytic complement (CH50) was determined by DiaMetra kit (Made in Italy) [21].

\section{Statistic analysis}

The data were analyzed with SPSS 20 . In order to determine the normal distribution of the data, we used Oneway anova. The abnormal distribution data were analyzed with Kruskal Wallis. For all statistical tests $P$ value $<0.05$ was considered.

\section{Results}

Following treatment of the fingerling trout fishes with two doses of folic acid (6 and $10 \mathrm{mg} / \mathrm{kg}$ food) for two months, the fishes were analyzed in terms of their length and biomass. The analyzed data, based on Oneway anova, showed that the fishes treated with both concentrations of folic acid were meaningfully taller than the controls $(\mathrm{P}<0.05)$ (Table 1). A same improvement pattern has been observed when the weight of the fishes was measured (Table 1).

Based on oneway anova and Kruskal Wallis analysis, the treatment also could improve the body weight gain Percentage (\%BWI). The index increased with both doses of folic acid, peaking at $10 \mathrm{mg}$. Although treatment of the fishes with $6 \mathrm{mg}$ folic acid could significantly increase the condition factor $(\mathrm{K})$, the index decreased suddenly with $10 \mathrm{mg}$ folic acid and no significant difference in $\mathrm{K}$ was seen between this dose and the control (Table 1).

Based on Oneway anova and Kruskal Wallis tests, the specific growth rate (SGR) of the treated fishes was in parallel to the folic acid dose (Table 1). Also, calculations showed that daily growth rates (DGR) of the treated fishes with folic acid was significantly higher than the control (Table 1). Based on these tests, the treatments with folic acid

\begin{tabular}{|l|l|l|l|}
\hline Parameters & Control & $\mathbf{6} \mathbf{~ m g}$ & $10 \mathrm{mg}$ \\
\hline Length & $12.39 \pm 0.73$ & $12.89 \pm 0.8 \mathrm{a}$ & $13.13 \pm 0.79 \mathrm{a}$ \\
\hline Weight & $20.3 \pm 3.38$ & $23.36 \pm 4.18 \mathrm{a}$ & $24.22 \pm 4.05 \mathrm{a}$ \\
\hline Body weight gain (\%BWI) & $216.52 \pm 9.52$ & $258.34 \pm 16.55 \mathrm{a}$ & $271.48 \pm 17.64 \mathrm{a}$ \\
\hline Specific growth rate (SGR) & $1.92 \pm 0.05$ & $2.13 \pm 0.08 \mathrm{a}$ & $2.19 \pm 0.08 \mathrm{a}$ \\
\hline Daily growth rate (DGR) & $3.61 \pm 0.16$ & $4.31 \pm 0.28$ & $4.52 \pm 0.29 \mathrm{a}$ \\
\hline Food conversional rate & $1.53 \pm 0.09$ & $1.3 \pm 0.2 \mathrm{a}$ & $1.24 \pm 0.1 \mathrm{a}$ \\
\hline (FCR) & & & \\
\hline Survival Rate & $1.07 \pm 0.02$ & $1.09 \pm 0.01$ & $1.07 \pm 0.01$ \\
\hline Condition Factor (K) & $100 \pm 0$ & $100 \pm 0 \mathrm{ac}$ & $100 \pm 0$ \\
\hline Erythrocyte cell count (106) & $0.81 \pm 0.08$ & $0.70 \pm 0.02 \mathrm{a}$ & $0.70 \pm 0.03 \mathrm{a}$ \\
\hline Hb (g/100ml) & $7.23 \pm 0.72$ & $6.23 \pm 0.18 \mathrm{a}$ & $6.26 \pm 0.27 \mathrm{a}$ \\
\hline Hematocrit & $35.33 \pm 5.5$ & $30 \pm 1 \mathrm{a}$ & $30.33 \pm 2.3 \mathrm{a}$ \\
\hline MCV & $420.66 \pm 7.24$ & $428 \pm 6.88 \mathrm{a}$ & $432 \pm 3.52 \mathrm{ab}$ \\
\hline MCH & $98 \pm 0.57$ & $88.66 \pm 0.33 \mathrm{ac}$ & $89.33 \pm 0.33$ \\
\hline MCHC & $20.66 \pm 0.33$ & $20.33 \pm 0.33 \mathrm{ac}$ & $20.66 \pm 0.33$ \\
\hline WBC (104) & $0.35 \pm 0.01$ & $0.52 \pm 0.07 \mathrm{a}$ & $0.66 \pm 0.02 \mathrm{ab}$ \\
\hline Neutrophil & $38 \pm 0.88$ & $28 \pm 0.55 \mathrm{a}$ & $27 \pm 1.73 \mathrm{a}$ \\
\hline Lymphocyte & $24 \pm 1.73$ & $25 \pm 1.0 \mathrm{a}$ & $25 \pm 3.51 \mathrm{a}$ \\
\hline Monocyte & $2.33 \pm 0.33$ & $2.66 \pm 0.33 \mathrm{a}$ & $2.33 \pm 0.33$ \\
\hline Eosinophil & $1.0 \pm 0.57$ & $1.33 \pm 0.33 \mathrm{a}$ & $2.0 \pm 0.57 \mathrm{ab}$ \\
\hline Total Immunoglobulin & $14.47 \pm 0.49$ & $14.3 \pm 1.8 \mathrm{a}$ & $16.53 \pm 0.32 \mathrm{ab}$ \\
\hline IgM & $16.66 \pm 0.88$ & $23.33 \pm 2.6 \mathrm{a}$ & $27.33 \pm 3.71 \mathrm{ab}$ \\
\hline Lysozyme & $26 \pm 2.64$ & $51 \pm 7.02 \mathrm{a}$ & $48.66 \pm 10.13 \mathrm{a}$ \\
\hline CH50 & $31.66 \pm 3.66$ & $50.33 \pm 10.68 \mathrm{a}$ & $37.33 \pm 7.42 \mathrm{a}$ \\
\hline
\end{tabular}

Table 1: Changes in biometric and blood factors of fingerling rainbow trout fishes (Oncorhynchus mykiss) treated with 6 and $10 \mathrm{mg}$ folic acid per kg food: $a$, b and $c(p<0.05)$.

decreased the food conversional rate (FCR), and the decreases in both concentrations were statistically significant (Table 1). According to Kruskal Wallis test, no meaningful differences were seen in the survival rate of the control and treated fishes (Table 1).

Furthermore, the folic acid treatment had different effects on RBC factors. Based on Oneway Anova, the treatment decreased significantly RBC counts, hemoglobin concentration and hematocrit; no differences were observed when the factors were compared between two doses of folic acid. The treatments, inversely, boosted mean corpuscular volume (MCV), and increase in dose of folic acid rose the index. Although treatment with $6 \mathrm{mg}$ decreased $\mathrm{MCH}$ and $\mathrm{MCHC}$, the indexes rose again and reached to the levels same as the controls (Table 1).

Even though the data showed significant increases in the total white blood cell count after treatment with folic acid $(\mathrm{P}<0.05)$, different results were achieved when the cells were analyzed separately with Oneway anova and and Kruskal Wallis tests (decrease in the neutrophils and increase in the lymphocytes and eosinophils). Monocytes showed a significant increase in $6 \mathrm{mg}$ folic acid but the level of this cell returned back to the control level when treated with $10 \mathrm{mg}$ folic acid (Table 1).

Finally, based on Oneway anova and and Kruskal Wallis tests, the treatment could significantly increase total immunoglobulins and mean IgM production in the fishes, and the concentration of immunoglobulin reached to highest point when the fishes were treated with $10 \mathrm{mg}$ folic acid (Table 1). Although a same improvement pattern was seen in the lysozyme activity, higher concentrations of folic acid had no extrabeneficiary (Table 1). Furthermore, the folic acid treatment increased CH50 index in the examined fishes, and although both concentrations showed significant increases, the index felled slightly at $10 \mathrm{mg} / \mathrm{L}$ folic acid (Table 1). 
Citation: Firouz A, Soheil L, Hossein K, Shabanali N, Mohammad B, et al. (2013) The Effects of Folic Acid Treatment on Biometric and Blood Parameters of Fingerling Rainbow Trout Fishes (Oncorhynchus mykiss). J Aquac Res Development 4: 175 doi:10.4172/2155-9546.1000175

\section{Discussion}

Since folic acid is an essential nutrient for animal's hematopoietic activity, regulation of blood glucose, improvement of cell membrane activity and finally eggs' hatchability in rainbow trout $(6-10 \mathrm{mg} / \mathrm{kg})$ [22,23], any deficiency in this factor leads to different physiological dysfunctions, including megaloblastic anemia, increased appetite and weight loss $[24,25]$.

In this study, the effects of two different doses of folic acid (6 mg and $10 \mathrm{mg}$ per each $\mathrm{kg}$ food) on growth performance, blood parameters and immune system of fingerling rainbow trout fishes (Oncorhynchus mykiss) were discussed. The doses were recommended by researchers as suitable folic acid concentrations for farming rainbow trout fishes: 6 mg per each $\mathrm{kg}$ food by NCR in 1981 [26] and 6-10 mg per kg food by Halver and Hardy [22].

Our result showed that treatments with both folic acid doses ( 6 and $10 \mathrm{mg} / \mathrm{Kg}$ dried food) for two months could improve the fish's biometric parameters in terms of length and weight. In addition to increase of body weight gain index (\%BWI) in higher doses, the treatments could improve the specific growth rate (SGR) of the fishes and daily growth rate (DGR). These obvious physical alternations were associated with increase in feeding efficiency and decrease in the food conversional rate (FCR). Although the treatment with $6 \mathrm{mg}$ folic acid dose was associated with fish condition $(\mathrm{k})$ improvement, the treatment with 10 $\mathrm{mg}$ was not successful in this term. The decrease of $\mathrm{k}$ at $10 \mathrm{mg} / \mathrm{L}$ despite improvement in other physical criteria showed that taking higher doses of the folic acid increased the fishes' length more than their weight (taller but thinner fishes).

The hematologic parameters render valuable information for biologists to determine the health status of fishes [27]. In this study, treatments with both folic acid doses led to decrease of RBC counts, hematocrit and hemoglobin concentration. Since the decrease of RBC count was not in parallel with increase of the RBC volume (MCH and MCHC indexes), it appears that the fishes had to increase the cell's volume and the mean concentration of hemoglobin per unit (MCV) in order to overcome on the blood deficiency. Totally, the results indicate that increase in folic acid dose does not improve blood parameters. This phenomenon can be interpreted by the reality that hematopoietic activity of animals, including fishes, is a result of synergy between a different essential factors, including vitamin B12, B6, K, E, D and folic acid as well as some minerals such as iron, zinc, copper and so on [28].

However, our result showed that the treatment with folic acid treatment could successfully improve the fish immune system. Although different white blood cells responded differently to treatment, total white blood cell (WBC) count increased significantly with both folic acid doses $(\mathrm{P}<0.05)$. Also, the improvement was supported with increases in total immunoglobulin levels, mean IgM production, lysozyme activity and $\mathrm{CH} 50$ index. It must be noted that the treatment with $10 \mathrm{mg}$ folic acid had no obvious positive or negative effect on total immunological factors. A same result was obtained when the effect of folic acid treatment on immunological system of Oncorhynchus tshawytscha was studied [4].

As a conclusion, despite the ineffectiveness of the folic acid treatment on survival rate and also despite the intensive decreases of red blood cell indexes at $10 \mathrm{mg}$, our results are congruent with the idea that treatments of the fingerling rainbow trout fishes with both folic acid doses (6 and $10 \mathrm{mg}$ per each $\mathrm{kg}$ taken dried food) had a similar effect on different physiological conditions of the fish, and extra- administration of this vitamin cannot improve fish growth conditions. It must be noticed that the taken supplementary elements and vitamins are variable based on size and age of fish. Furthermore, since folic acid is not the only taken supplementary factor (macro/microelements and vitamins) for fish farming, the effects of each factor needs to be interpreted with the respect to the synergic or antagonistic effect(s) of other effective elements on fish growth. Such these synergisms have been seen, for instance, between niacin and folic acid [4] and between vitamin $\mathrm{C}$ and Folic acid [3].

\section{Acknowledgment}

The authors would like to appreciate Islamic Azad University (Lahijan branch) for their financial and technical supports.

\section{References}

1. FAO (2011) FAO Workshop on Future Directions for Gender in Aquaculture and Fisheries Action, Research and Development, FAO Fisheries and Aquaculture Report No. 998, Rome, Shanghai, China.

2. Brown EE, Gratzek JB (1980) Fish Farming Handbook. AVI Publishing Co. Westport, CT.

3. Hien DV, Doolgindachbaporn S (2011) Effect of Niacin and Folic Acid in Feed Rations on Growth and Live Weights of Green Catfish (Mystus nemurus Valenciennes 1840). Pak J Biol Sci 14: 64-68.

4. Shafaeipour A, Gorjipour E, Kamayi K, Falahatkar B (2011) Effects of Different Levels of Folic Acid and Vitamin C on Rainbow Trout, Oncorhynchus mykiss. Journal of the World Aquaculture Society 42: 281-286.

5. Verlhac V, Gabaudan J (1994) Influence of vitamin C on the immune system of salmonids. Aquaculture Research 25: 21-36.

6. Bell JG, Cowey CB, Adron JW, Shanks AM (1985) Some effects of vitamin $\mathrm{E}$ and selenium deprivation on tissue enzyme levels and indices of tissue peroxidation in rainbow trout (Salmo gairdneri). Br J Nutr 53: 149-157.

7. Wilson RP, Bowser PR, Poe WE (1984) Dietary vitamin E Requirement of fingerling channel Catfish. J Nutr Sci 114: 2053-2058.

8. Craig S, Helfrich LA (2002) Understanding fish Nutrition, Feeds and Feeding Virginia Cooperative Extension: 1-18

9. Popovic NT, Strunjak-Perovic I, Coz-Rakovac R, Barisic J, Jadan M, et al (2012) Tricaine methane-sulfonate (MS-222) application in fish anaesthesia Journal of Applied Ichthyology 28: 553-564.

10. Stephen Drummond Sedgwick (1995) Trout Farming Handbook. John Wiley and Sons, UK.

11. Ebrahimi G (2011) Effects of rearing Tank Background Color on Growth performance in juvenile Common carp, Cyprinus carpio L. Agricultural Journal 6: 213-217.

12. Hung SS, Slinger SJ (1982) Effect of dietary vitamin E on rainbow trout (salmo gairdneri). Muscle alpha-tocopherol and storage stability. Int J Vitam Nutr Res 52: $120-125$.

13. Blaxhall PC, Daisley KW (1973) Routine haematological methods for use with fish blood. J Fish Biol 5: 771-781.

14. Vazquez GR, Guerrero GA (2007) Characterization of blood cells and hematological parameters in Cichlasoma dimerus (Teleostei, Perciformes) Journal of Tissue and Cell 39:151-160.

15. Simmons A (1997) Hematology. Butterworth-Heinemann: 507

16. Sniezko SF (1960) Microhaematocrit as a tool in fisheries management Special Scientific Report Fisheries. No.314.US. Department of International Fish and Fisheries Wildlife: 15

17. Seiverd CE (1964) Hematology for medical technologist s. Lea and febiger Philadelphia, USA.

18. Jaafar RM, Skov J, Kania PV, Buchmann K (2011) Dose Dependent Effects of Dietary Immunostimulants on Rainbow Trout Immune Parameters and Susceptibility to the Parasite Ichthyophthirius Multifiliis. Journal of Aquaculture research and development 3: 8 .

19. Tietz NW (1986) Textbook of Clinical Chemistery. Saunders: 579 
Citation: Firouz A, Soheil L, Hossein K, Shabanali N, Mohammad B, et al. (2013) The Effects of Folic Acid Treatment on Biometric and Blood Parameters of Fingerling Rainbow Trout Fishes (Oncorhynchus mykiss). J Aquac Res Development 4: 175 doi:10.4172/2155-9546.1000175

20. Zilva JF, Pannall PR (1984) Clinical Chemistry in diagnosis treatment. LioydLuke. 348-352.

21. Miller GW, Nussenzweig V (1975) PNAS, 72: 418.

22. Halver J Hardy R (2002) Fish Nutrition (3rdedn), 839.

23. Halver JE (1989) The vitamins. In: Fish Nutrition, (2ndedn), Academic Press, New York, USA.

24. Cowey CB, Woodward B (1993) The Dietary Requirement of Young Rainbow Trout (Oncorhynchus mykiss) for Folic Acid. J Nutr 123: 1594-1600.
25. McLaren BA, Keller E, O'Donnell DJ, Elvehjem CA (1947) The nutrition of rainbow trout; studies of vitamin requirements. Arch Biochem 15: 169-178.

26. Harper HA, Rodwell VW, PA Mayes (1979) Review of physiological chemistry (17thedn), Lange Medical Publications, Los Altos, USA

27. Asadi MS, Mirvaghefei AR, Nematollahi MA, Banaee M, Ahmadi K (2011) Effects of Watercress (Nasturtium nasturtium) extract on selected immunological parameters of rainbow trout (Oncorhynchus mykiss). Veterinary Journal 2: 32 39.

28. Choi JW, Kim SK (2005) Relationships of Lead, Copper, Zinc, and Cadmium Levels versus Hematopoiesis and Iron Parameters in Healthy Adolescents. Ann Clin Lab Sci 35: 428-432. 